\title{
29. COMPARATIVE STRATIGRAPHY AND STRUCTURE OF THE WESTERN AUSTRALIAN MARGIN AND THE ADJACENT DEEP OCEAN FLOOR
}

\author{
J. J. Veevers, Macquarie University, Sydney, N.S.W. Australia \\ and \\ M. H. Johnstone, West Australian Petroleum Pty. Ltd., Perth, Australia
}

\section{INTRODUCTION}

By the time it ruptured from its neighbor in Gondwanaland, the Western Australian margin (Figure 1) had undergone a 140-m.y.-long phase of rifting, as recorded in the Permian to Jurassic/Cretaceous structures and sedimentary sequences (Figure 2). With rupture in the Jurassic to Cretaceous, as dated by the basal sediments at Sites 259,261, and 263, the continental margin and newly formed ocean floor underwent a phase of adjustment until the later Cretaceous (Santonian). At this time, the ocean may be considered to have reached maturity, and a new sedimentary regime, which has persisted to the present day, came into being. In this chapter, the connections between the contemporaneous continental margin and oceanic sequences and the relationships between continental and oceanic structure are explored.

\section{Late Paleozoic, Mesozoic, and Cenozoic Depositional History of Western Australian Margin}

We summarize the late Paleozoic, Mesozoic, and Cenozoic history of the continental margin by the stratigraphic diagrams of Figures 3 and 4 , graphic logs (Figures 5-7) of selected offshore wells (Pendock, Bedout, Scott), and cross-sections of parts of the Perth, Carnarvon, and Bedout basins (Figures 8-10). The history is grouped in three phases: rifting, juvenile ocean, and mature ocean (Figure 2).

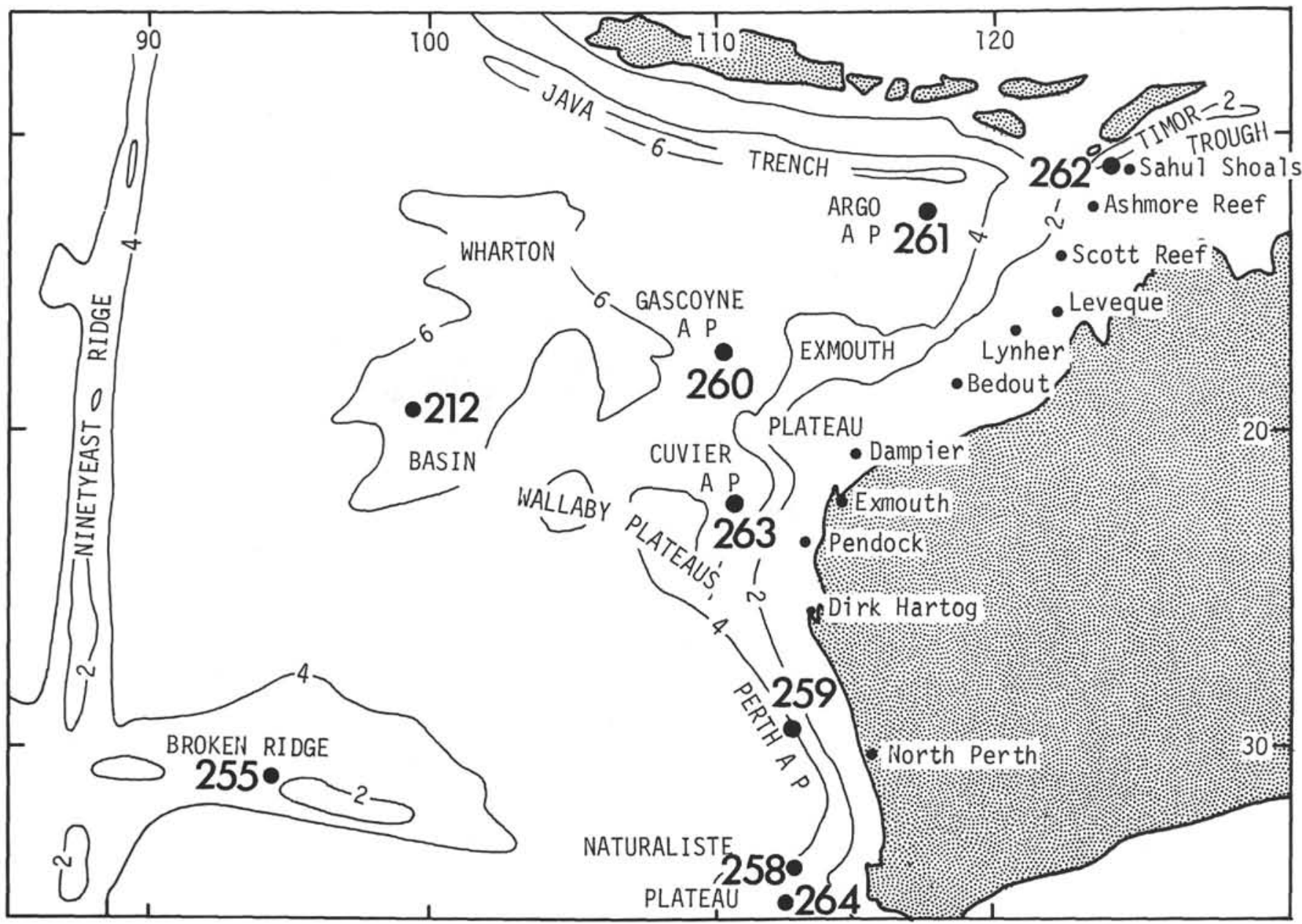

Figure 1. Eastern Indian Ocean and Western Australia, showing location of features mentioned in this paper. Bathymetry in $\mathrm{km}$. 


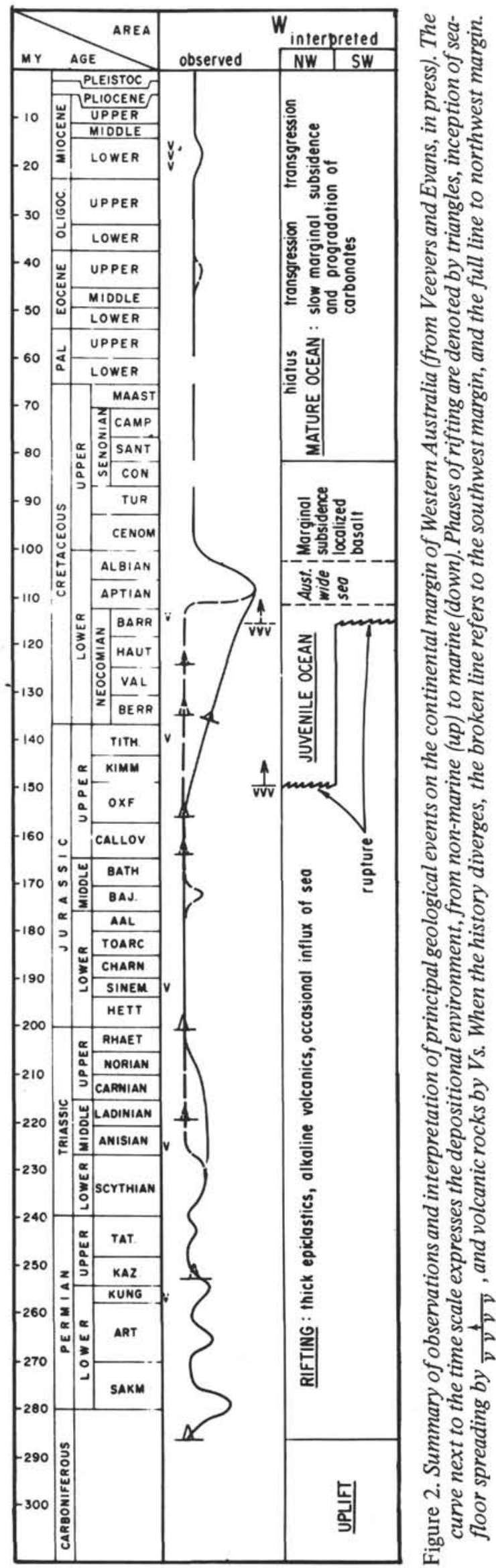

\section{Rifting}

Starting in the early Permian and extending to the middle of the Neocomian, the southwest margin underwent a phase of rifting during which fault-bounded troughs (grabens) received thick epiclastic sediments and occasional alkaline volcanic rocks. In the southern part of the Perth Basin, the sediments are wholly nonmarine (Veevers, 1971) and are replaced northward by marine sequences. The main pulses of rifting were in the early Permian, Kazanian, middle Triassic, and Middle to earliest Late Jurassic. In the northwest, thick sediments from late carboniferous to Early Jurassic were deposited in tectonically quiescent embayments and wide shelves. The development of the typical fault-bounded graben occurred in the Jurassic only, and the pre-Jurassic horsts seen in Figure 10 were produced during the initial phase of this event. After the rupture of the northwest margin in the Middle to Late Jurassic, the southwest margin underwent an additional pulse of rifting in the Late Jurassic and in the Neocomian. The intensity of the final diastrophism is shown in the cross-section off Perth (Figure 8), which shows a relief on the intra-Neocomian unconformity of 1250 meters. Further details of the unconformity are given by Jones and Pearson (1972). At Barrow Island, at the other end of the southwest margin, a depocenter supplied by the ancestral Robe and Ashburton rivers filled with thick $(1000 \mathrm{~m})$ deltaic sediments during the Tithonian and Neocomian (Crank, 1973).

\section{Juvenile Ocean}

Rupture of the rifted continental crust and emplacement of oceanic basalt along a spreading ridge in the Middle to Late Jurassic off the northwest margin and in the late Neocomian off the southwest margin initiated a phase of juvenile ocean development that lasted until the Santonian. The initial spreading was accompanied by the local eruption of basalt on the continental margin followed by a marginal marine transgression. These events took place during the Late Jurassic along the northwest margin where the transgression continued to a peak in the Aptian and during the late Neocomian/earliest Aptian along the southwest margin. In the southwest, the main deposit of the marine transgression was shale, locally sandy at the base, and, as seen in Figures 8 and 9, it smoothed out the high topographical or structural relief of the underlying unconformity. In accord with the earlier spreading off the northwest margin, here the transgressive marine deposits are Middle to Late Jurassic and Early Cretaceous, and they succeed nonmarine Early Jurassic sandstone and claystone which smooth out the relief in the underlying Triassic rocks (Figure 10).

The juvenile ocean phase may be considered to have lasted up to the Santonian, and the marginal deposits of this ocean were dominantly detrital (Figure 4). Locally, as on the Naturaliste Plateau and in the Bedout and Scott Reef exploration wells, carbonate sediments accumulated before the Santonian, but only from the Santonian did they become widespread. 


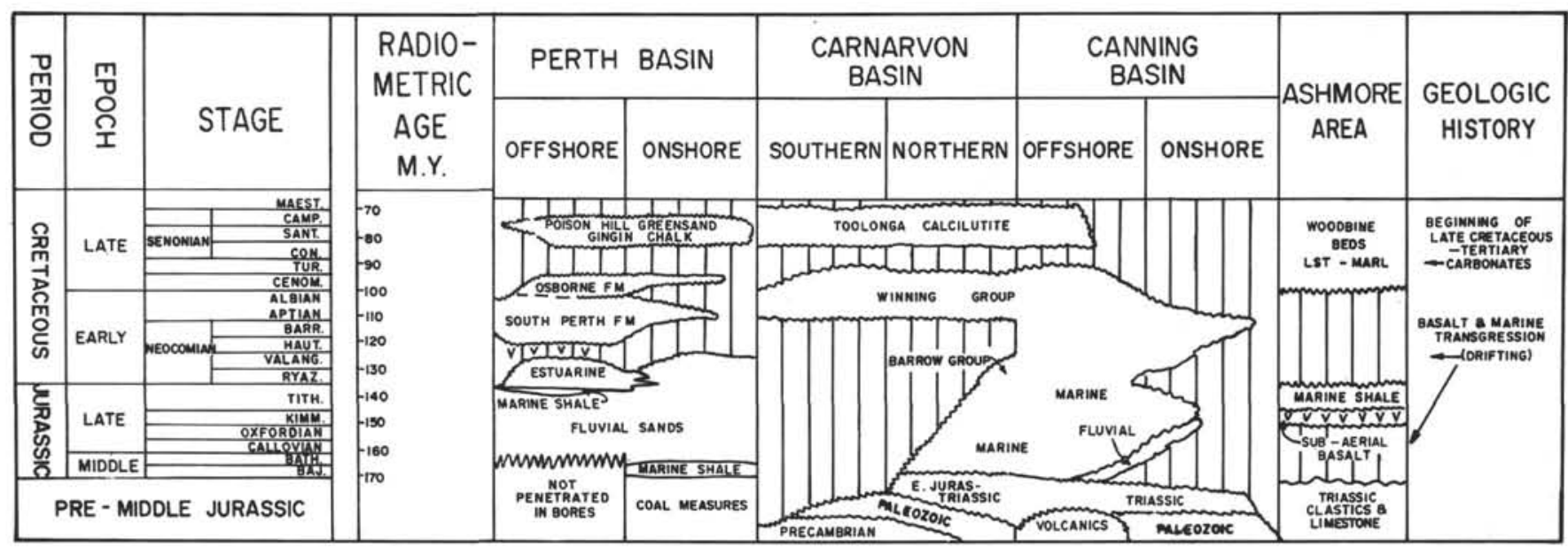

Figure 3. Diagram of the Mesozoic and earlier stratigraphy of the marginal sedimentary basins of Western Australia.

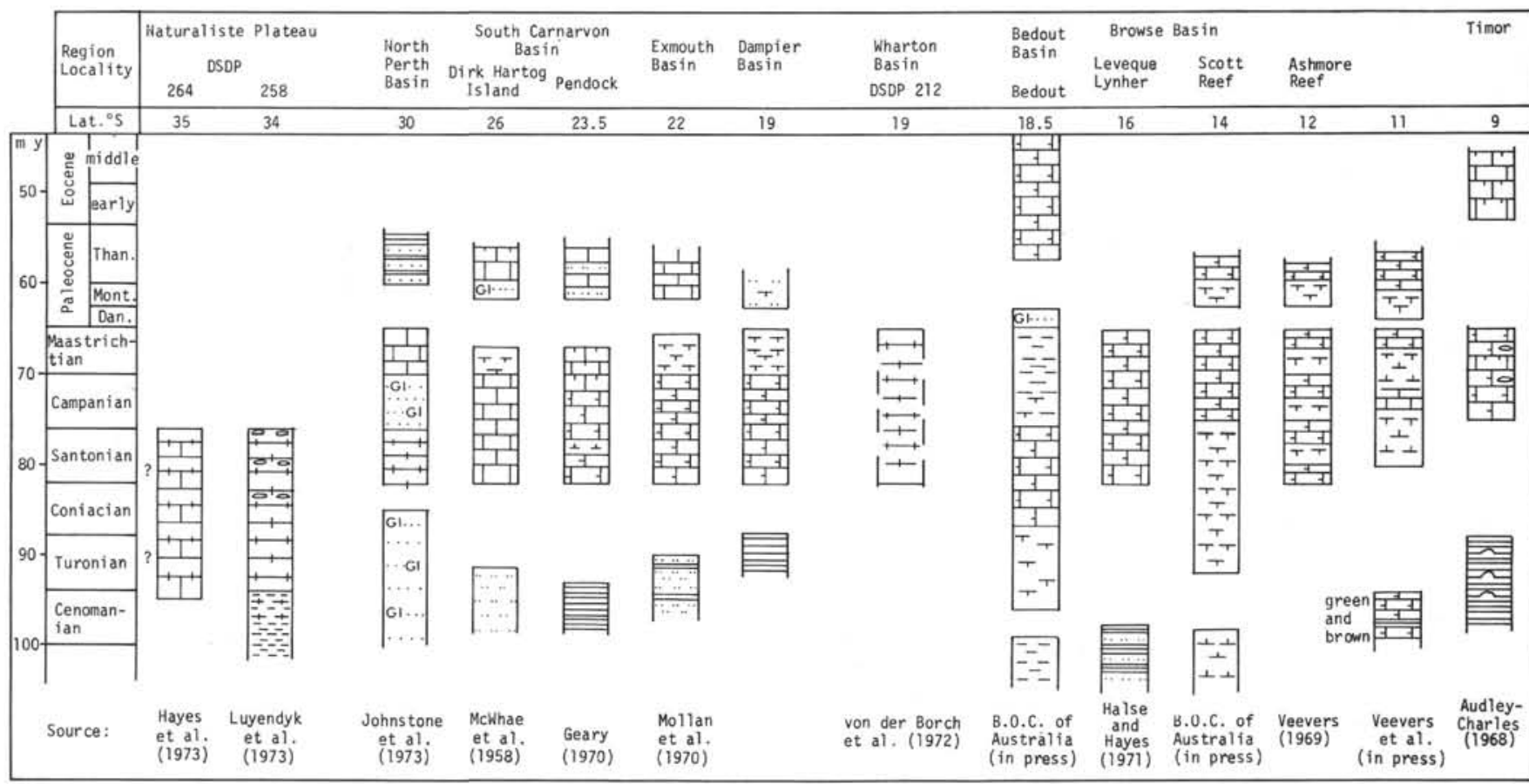

chlimestone

$\therefore$ siltstone $\quad$ ci....... glauconitic sandstone,

Figure 4. Time-stratigraphic columns for the interval Late Cretaceous to Eocene, arranged from south (left-hand side) to north (right-hand side), showing the hiatus at most localities during the Turonian and Coniacian, with predominantly detrital sediments below, and carbonate sediments above, and the Danian hiatus in carbonates.

To provide a basis of comparison with the deep-sea sites, a description of the Aptian-Cenomanian sequence of the Carnarvon Basin, called the Winning Group, is given here. A section of this sequence is shown in the graphic log of Pendock-1 Well (Figure 5), and it comprises Aptian quartzose sandstone at the base succeeded by Aptian to Cenomanian dark gray shale, in places glauconitic and silty. The sequence of the Winning Group in the onshore Carnarvon Basin (Condon, 1965-68) is a basal quartz sandstone (Birdrong Formation), the Muderong Shale, the Windalia Radiolarite, and the Gearle Siltstone. The Birdrong Formation, a basal transgressive sand, grades upwards into the Muderong Shale, which in the type area is gray ben- 


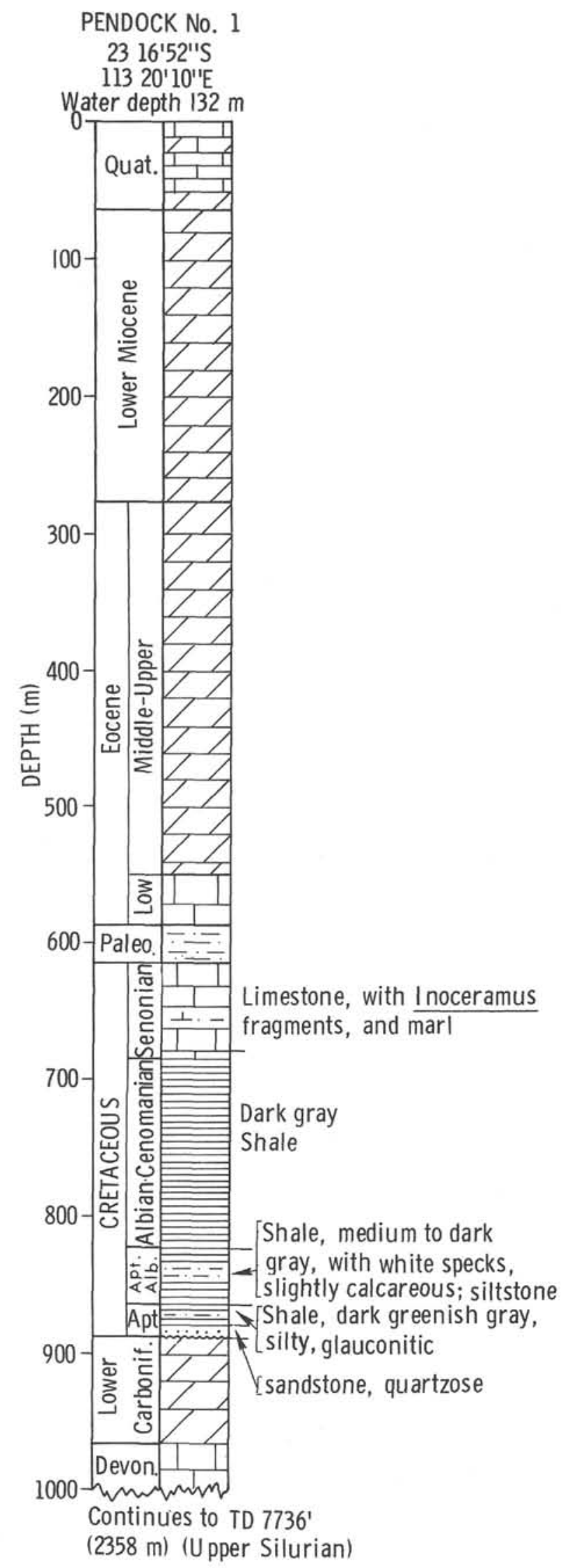

Figure 5. Graphic log of Pendock-1 Well, compiled from Geary (1970).

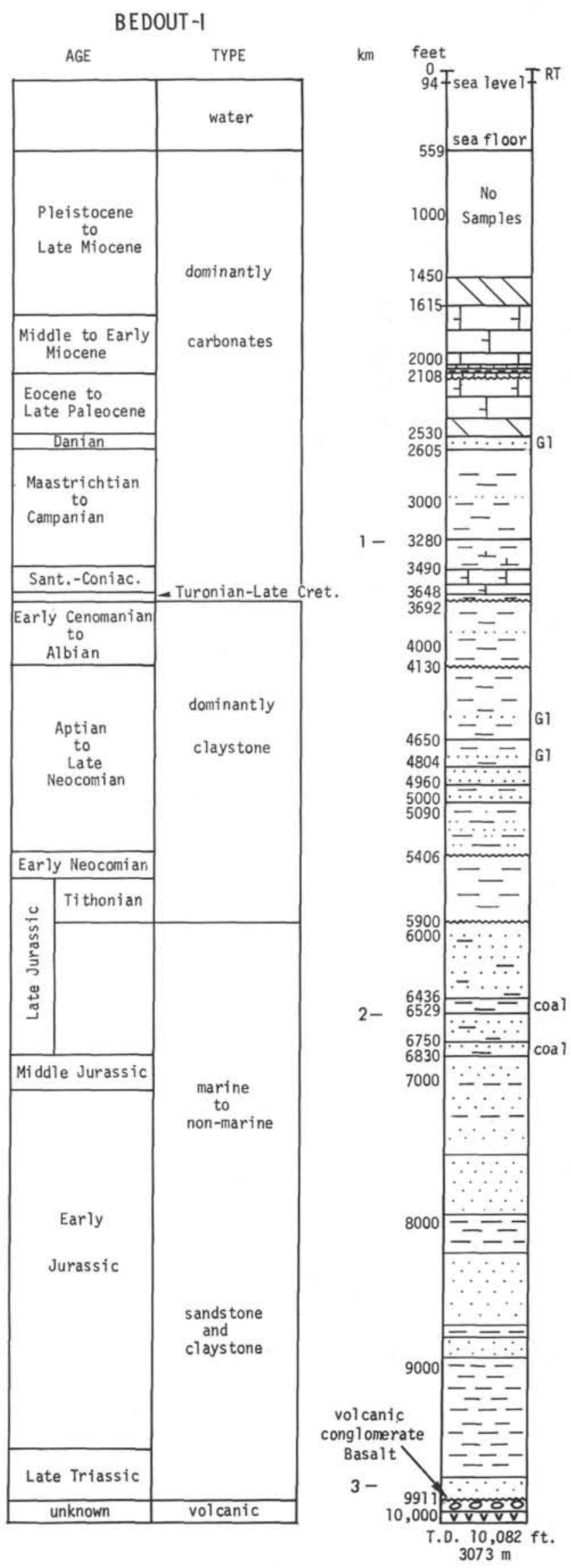

Figure 6. Graphic log of Bedout-1 Well, compiled from B.O.C. of Australia (in press). 


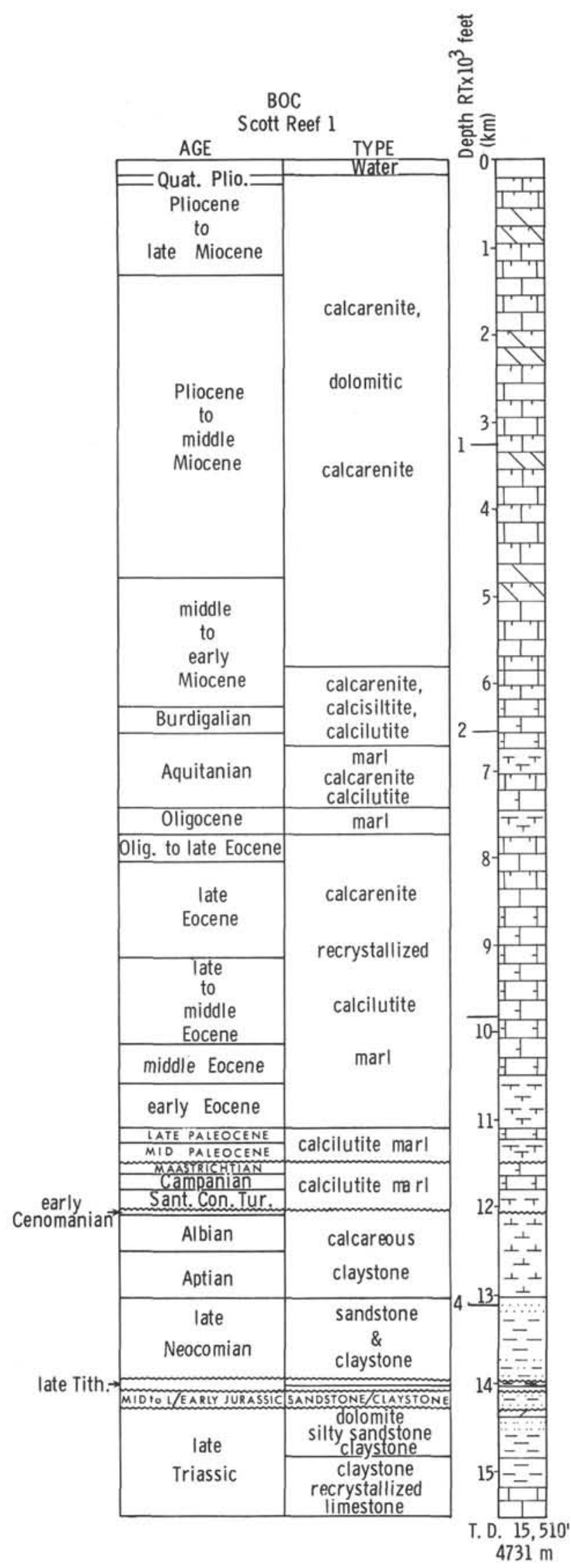

Figure 7. Graphic log of Scott Reef-1 Well, compiled from B.O.C. of Australia (in press). tonitic shale and claystone, silty towards the base. Elsewhere it is glauconitic and is at least 200 meters thick. It is a marine shale probably deposited in an open sea of only moderate depth. The main control on lithology appears to have been a low rate of supply of mainly finegrained sediment from a reduced hinterland. Foraminifera, microplankton, belemnites, Lingula, and bivalves are the only fossils found. The conformably overlying Windalia Radiolarite comprises laminated to thin-bedded radiolarite, radiolarian claystone and chert, and minor limestone, greensand, and siderite. Its thickness exceeds 100 meters. Besides Radiolaria, the Windalia contains foraminifera, ostracods, ammonites, belemnites, and bivalves, and its age is Aptian-Albian. It is thought to have been deposited in water of no more than moderate depth. The conformably overlying Gearle Siltstone consists of dark gray bentonitic siltstone and claystone with a few thin beds of radiolarite, barite, clay pellets, and glauconitic sand. White specks of unidentified, but probably bentonitic, material and disseminated pyrite are locally common. The greatest known thickness of the Gearle Siltstone is 600 meters. Foraminifera indicate an Albian to Turonian age. Other fossils are ostracods bivalves, and belemnite guards. Like the Windalia Radiolarite, its depositional environment is thought to have been a neritic sea with a reduced supply of fine-grained terrigenous sediment.

The tops of equivalent sequences elsewhere along the Western Australian margin and in Timor are shown in Figure 4 and are seen to be essentially the same as those described above from the Carnarvon Basin.

\section{Mature Ocean}

With the few apparent exceptions shown in Figure 4, the Coniacian and part of the Turonian are a regional hiatus along the entire margin, and the underlying dominantly detrital sequence is overlain by Santonian and younger, dominantly carbonate, rocks. The apparent exceptions are (1) the two DSDP sites on the Naturaliste Plateau, which span what is a hiatus elsewhere with carbonate sediment-at Site 258 the boundary between detrital rock and carbonates is Cenomanian/Turonian, and Turonian carbonate ooze has been cored elsewhere on the Naturaliste Plateau (Burckle et al., 1967); and (2) Bedout-1 and Scott Reef1 , which likewise have carbonate rock occupying much of the interval Coniacian and Turonian, though still with a hiatus (in the Cenomanian) between a detrital sequence below and a carbonate sequence above.

A second regional hiatus is the Danian or earliest Paleocene, and only one exception, Bedout-1, is known.

For our purposes, it is sufficient to point out these two hiatuses as they are revealed from the biostratigraphical information given in the completion reports of the subsidized wells. Further study should now be made to determine the time relations of these hiatuses more precisely. In the meantime, we offer the following speculations to account for the change from detrital to carbonate deposition in the Senonian:

1) At this time, the juvenile Indian Ocean attained maturity with the initiation of a thermohaline circulation of oceanic waters. The concomitant recycling of 


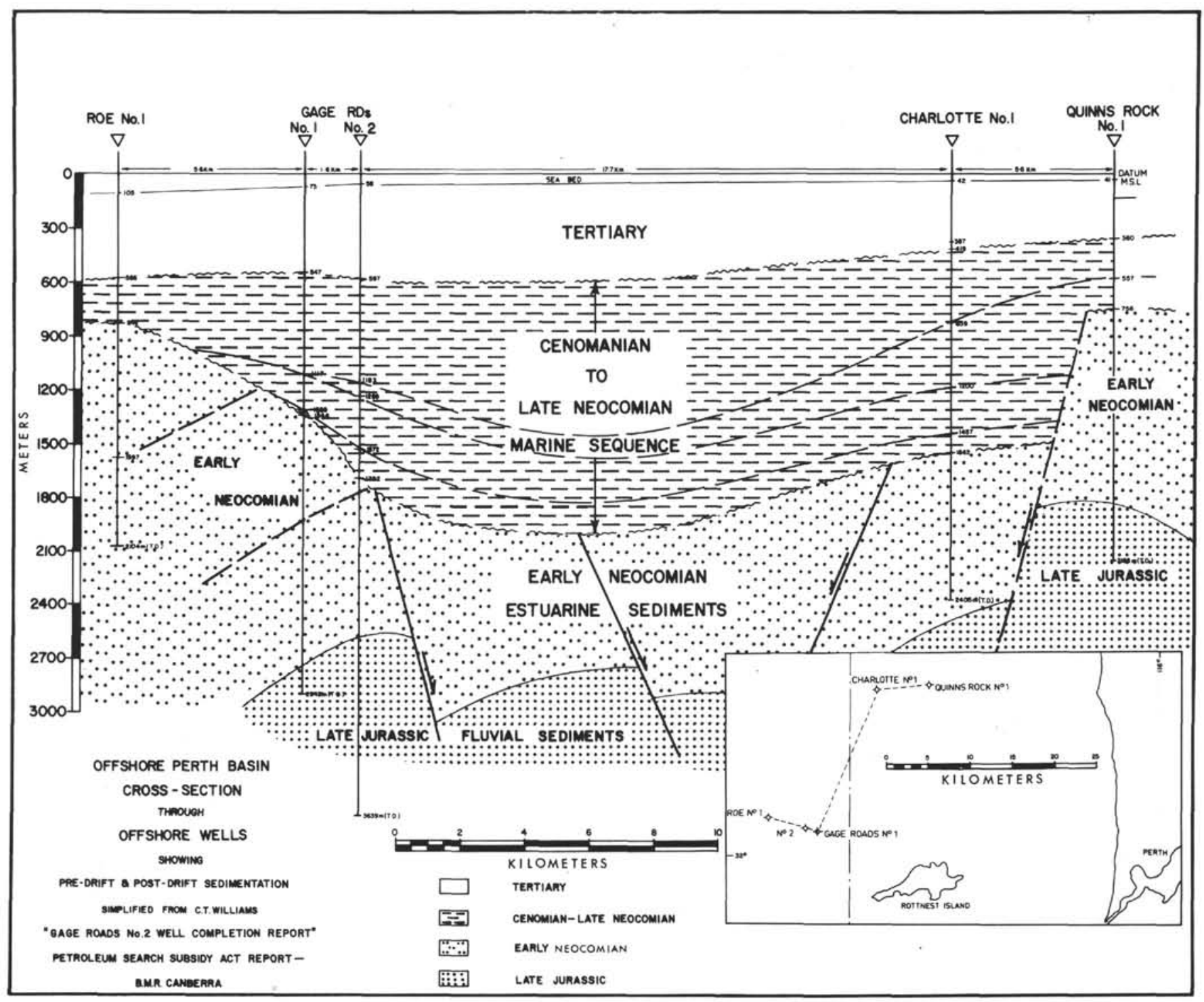

Figure 8. Cross-section through offshore wells of the Perth Basin, from Williams (in press). Vertical exaggerations 5.5:1.

organic nutrients increased the production, and hence the accumulation, of shallow-water carbonates. Additionally, some circulation of seawater in a shallow seaway that covered the boundary between Australia and Antarctica was initiated by the Late Cretaceous (Veevers and Evans, in press; McGowran, 1973).

2) The Maestrichtian/Campanian interval was a time of rapid accumulation of mainly carbonate sediment in the present tropical Pacific (Moore, 1972, fig. 5), and the Paleocene and Santonian/Coniacian were times of slow sediment accumulation. If these were global events, they would have influenced the distribution of carbonate along the Western Australian margin.

3) Australia apparently started wandering northward at the beginning of the Late Cretaceous (Wellman et al., 1969), and by the Santonian it may have reached a critically warmer latitude that favored the deposition of carbonate sediments. This is the weakest of the three speculations, because, with the few exceptions noted above, the onset of carbonate deposition is synchronous over the $26^{\circ}$ of latitude of the western margin, whereas according to this speculation, carbonate deposition would be expected to have started in the north and slowly extended southward. In fact, one group of the earliest recorded carbonates in the region is on the Naturaliste Plateau, at the southern limit of the western margin.

One oceanic site, DSDP Site 212 in the deep Wharton Basin, is included in Figure 4 (the Naturaliste Plateau is regarded as continental). At Site 212 (Sclater et al., 1974), oceanic basalt is overlain by barren brown clay alternating with thick layers of carbonate chalk or ooze, thought to have been transported from areas above the calcium carbonate compensation level to the deep basin by slumping or bottom current activity. The oldest fossils in the deepest carbonate layer are Santonian, and they are mixed with fossils as young as late Maestrichtian. We conclude that the sequence at Site 212 reflects the original accumulation in shallower water of Santonian and younger carbonates that were first displaced into the Wharton Basin during the late Maestrichtian. 


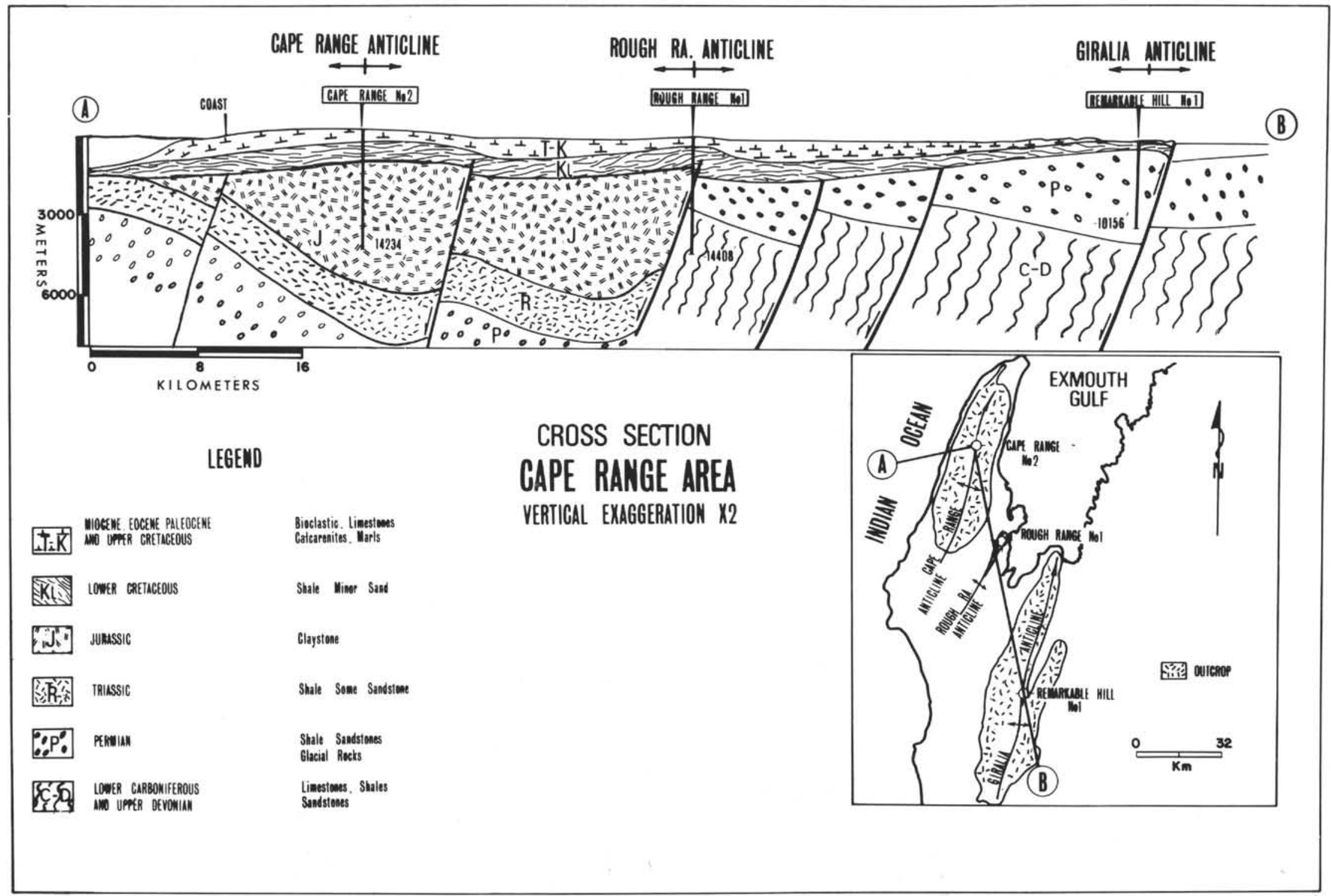

Figure 9. Cross-section of the Cape Range area, to show the overlap of Aptian and younger sediments across the preexisting|surface of high structural relief. 


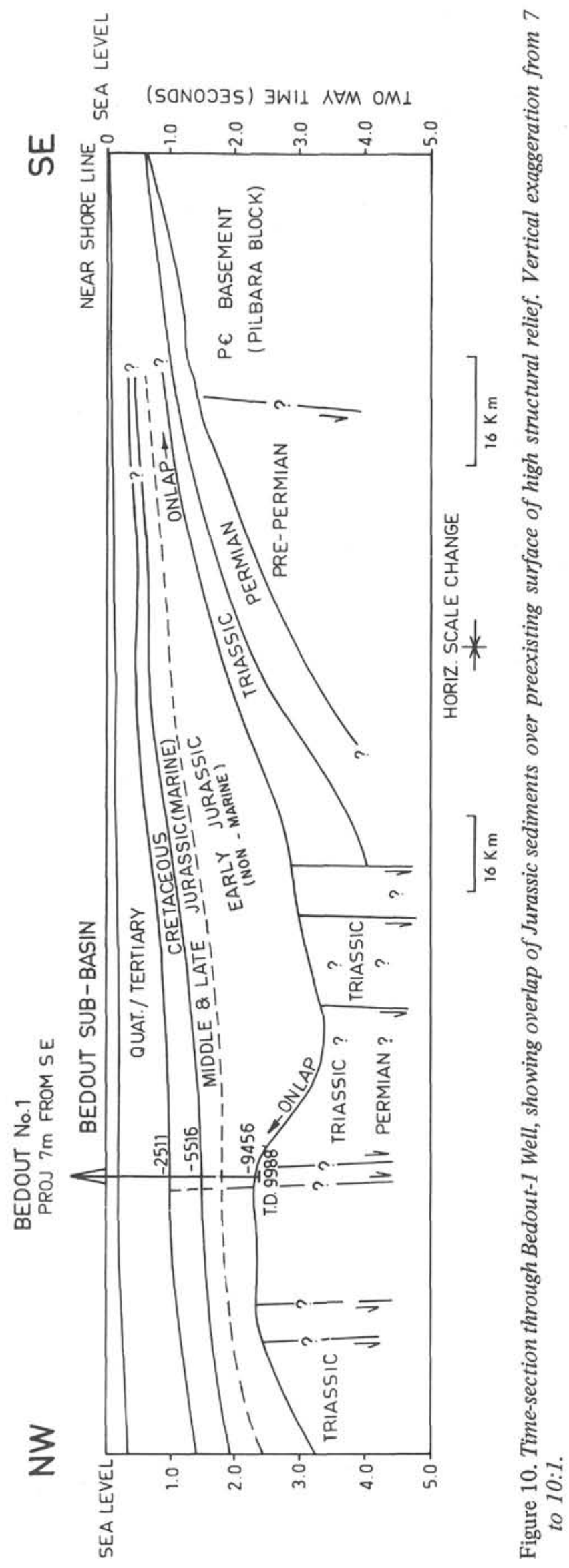

As seen along the Western Australian margin, most completely in Scott Reef-1 (Figure 7), the deposition of carbonate rocks continued through the Late Cretaceous to the present day, with only the one hiatus in the Danian. On Timor, the Danian hiatus is part of a longer Paleocene hiatus due to a phase of thrusting. Elsewhere along the Australian margin, the Danian hiatus is due either to scouring by currents that resulted from a radical change in circulation that accompanied the Paleocene initiation of sea-floor spreading between Australia and Antarctica or to the above-mentioned low accumulation rates of the Paleocene, or a combination of the two effects.

\section{Comparison of Marginal Oceanic and Continental Stratigraphy}

As described elsewhere in this volume, the oceanic sequence beneath the abyssal plains is divisible into a seismically transparent Late Jurassic to Early Cretaceous clay or claystone that drapes oceanic basalt, and a younger, horizontal, well-stratified sequence of displaced carbonates.

A direct link between the continental margin and oceanic Early Cretaceous sequences is provided by the seismic profile between Pendock-1 Well and Site 263 (Veevers, Regional Surveys, this volume). With the assumption that the base of Site 263 is very close to acoustic basement, this profile shows that the Early Cretaceous sequences at Site 263 and Pendock-1 are correlative (Figure 11). The exact time relations between these sequences are uncertain due to the conflicting dating of the sequence at Site 263 by nannoplankton and dinoflagellates (both alternatives are given in Figure 11), but in any case both sequences lie within the interval Aptian (or slightly older) to Cenomanian. The lithological similarities are striking: both sequences are dark gray to black pelites, with glauconitic beds, and both are sandy towards the base. Further details from the sequence of this age in the rest of the Carnarvon Basin, called the Winning Group, support the correlation. As in the sequence at Site 263, the Winning Group is bentonitic, contains barite nodules, and has a biota of foraminifera, belemnites, dinoflagellates, ostracods, bivalves, and ammonites. The only apparent difference is the frequent occurrence of Radiolaria in the Winning Group and their scarcity at Site 263. The conclusion seems inescapable that the Lower Cretaceous sequence at Site 263 is part of the Winning Group, and, though now in an oceanic setting (the base of Site 263 is $5811 \mathrm{~m}$ below sea level), was deposited in a fairly shallow environment. Site 263 therefore records the history of an embryonic ocean basin, as outlined in Figure 12. The contraints on Figure 12d are the drilled sections of Site 263 and Pendock-1 (Figures 5, 11), and the seismic profile linking these drill holes (see Regional seismic surveys). The sketch sections of the three earlier epochs (Figures $12 \mathrm{a}-\mathrm{c}$ ) are arranged with the edge of the continent, and hence Pendock-1, in a fixed position with respect to each other and to Figure 12d, so that from Figure 12 a-c the spreading axis migrates progressively westward. The gross constraints on the depth of the sea in Figures $12 \mathrm{a}-\mathrm{c}$ are set by determination of paleobathymetry in the two drill holes. Thus, the site of 
263

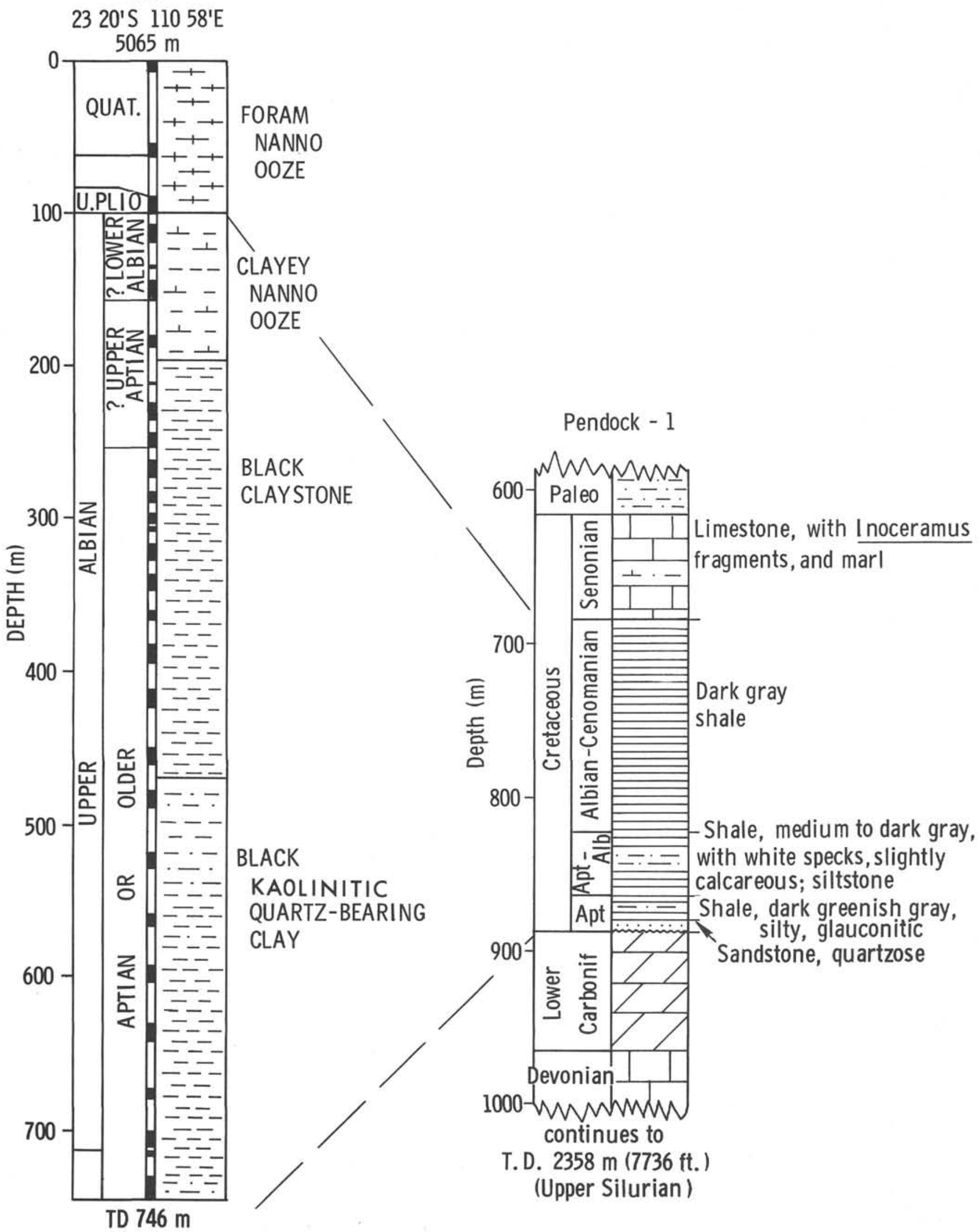

Figure 11. Comparison of stratigraphic sections of Site 263 and Pendock-1 Well. 


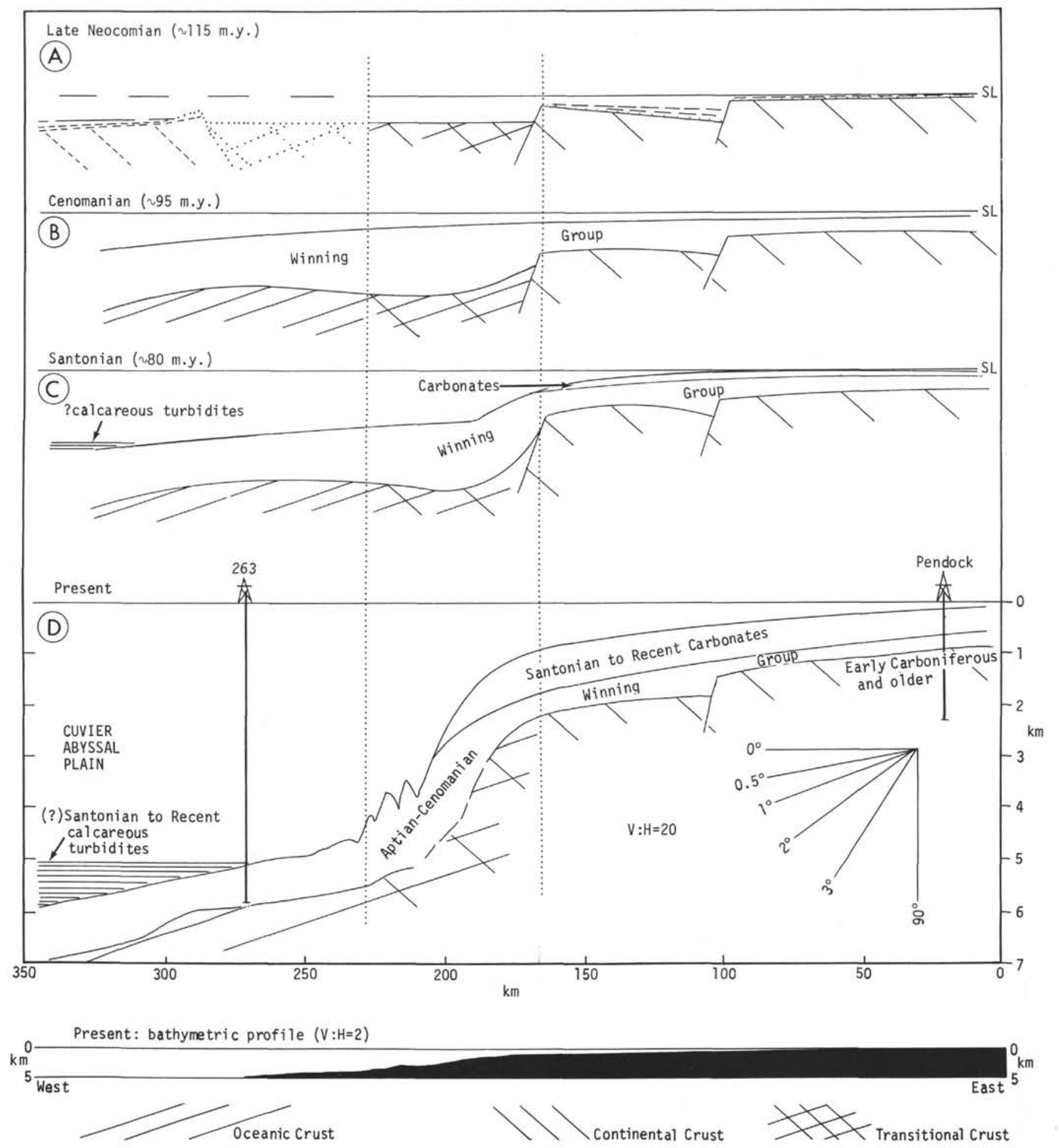

Figure 12. Diagrammatic sections of the Site 263-Pendock continental margin, showing its evolution from the Neocomian, and inferred distribution of continental, transitional, and oceanic crust. (a) Late Neocomian, (b) Cenomanian, (c) Santonian, (d) Present.

Pendock-1 is shallow during the Cretaceous and Cenozoic, while the original site of 263 is shallow in the early Aptian or older (between a and b), and deeper (but not abyssal) in the Albian. The appearance of carbonates on the shelf in the Santonian provides a source of the fine carbonates deposited in depressions in the deeper sea floor by bottom flows. Between the Santonian and the present, with the further separation of the oceanic margin from the spreading ridge, this marginal region subsided to its present depth, and the continued piling up of carbonate sediments on the continental-oceanic margin led, by slumping of its edges, to further deposi- 
tion of calcareous bottom flow deposits on the Cuvier Abyssal Plain.

Of considerable structural interest is the apparent continuity across the continental slope of the pre-Aptian basement. In the absence of a significant marginal gravity anomaly (J. C. Branson, personal communication), the continuous increase in the depth to basement across the margin must imply a transition in its density from continental to oceanic crustal values. We have no indication of the nature of this transition, but an obvious possibility is the mixing (by dike injection) of oceanic with continental crustal material during rupture.

In contrast to Site 263, Site 259 is separated from the continental margin by the Wallaby-Perth scarp, which cuts across the structure of the margin (see Figure 2 of regional surveys). As a result, there is no continuity of structure from the ocean to the continent in the region of Site 259, and links can be sought through stratigraphic comparisons only.

In the latter half of the Early Cretaceous, the Perth Basin underwent a period of diastrophism, which is recorded in the intra-Neocomian unconformity (Figure 8). Then came eruption, at the continental termination of the fracture zone of the Wallaby-Perth scarp, of the terrestrial Bunbury Basalt at the southern end of the basin, subsidence of the continental margin causing a marine transgression, and the deposition of the late Neocomian to Aptian South Perth Shale and Albian and younger marine sandstone formations.

The sequence at Site 259 generally matches the Perth Basin sequence of basalt and Aptian shale, but differs from it in detail (Figure 13): the Bunbury Basalt is terrestrial, the basalt at Site 259 is marine; the South Perth Shale is a shallow marine deposit, the Aptian zeolitic clay of Site 259 is presumably a deeper-water deposit. The Albian deeper-water calcareous and argillaceous sequence at Site 259 contrasts with the shallow marine sandstones of the Perth Basin. However, the Late Cretaceous and early Paleocene hiatus of Site 259, followed by late Paleocene and early Eocene brown clay and ooze, again matches the depositional sequence of parts of the Perth Basin, in particular that of the Perth area itself, in which the Albian to Cenomanian Osborne Formation is unconformably overlain by the late Paleocene to early Eocene Kings Park Shale.

Unlike Sites 263 and 259, which are immediately adjacent to the margin, Site 261 is situated about $150 \mathrm{~km}$ from the continental margin and $450 \mathrm{~km}$ from the closest continental drill hole, and, consequently, the stratigraphic relations between Site 261 and the margin are likely to be less obvious than those to the south. Furthermore, the broad offshore part of the continental margin has few drill holes so that the marginal stratigraphy is poorly known.

A Jurassic marine transgression is indicated onshore by Oxfordian and Kimmeridgian siltstone and shale (Jarlemai Siltstone, Alexander Formation) that succeed older Jurassic fluvial sandstone, and offshore (Scott Reef-1, Bedout-1, Rob Roy-1) by Middle Jurassic nearshore deltaic sands that unconformably overlie Early Jurassic nonmarine or Triassic marine sandstone. The same transgression is recorded in some of the wells in the Timor Sea area. In the offshore Canning Basin, the transgression had its farthest extent in the Aptian, and, with the possible exception of hiatuses in the early late Cretaceous and early Paleocene, has persisted to the present day (Figure 10).

Late Tithonian basalt is recorded in Scott Reef- 1 and Late Jurassic or Early Cretaceous basalt in Ashmore-1. The basalt in Scott Reef-1 is only a few meters thick and is probably marine, whereas in Ashmore-1 the basalt is 300 meters thick and is probably terrestrial.

Unlike the southwest margin, which at its extreme in the south Perth Basin has entirely nonmarine strata up to the late Neocomian to Aptian transgression (Veevers, 1971), the northwest margin has a long earlier Mesozoic and Permian marine record, which may reflect its proximity to a pre-Late Jurassic ocean (Veevers et al., 1971).

For the purpose of comparison with the oceanic sequence (revealed by Sites 260 and 261), a composite qualitative stratigraphic section of the northwest margin, based on Scott Reef-1, supplemented by Bedout-1, is shown in Figure 14. The late Tithonian basalts of Scott Reef-1 and Ashmore Reef-1 are at least 10 m.y. younger than the basalt at Site 261 and are probably late-stage eruptions at the continental terminations of oceanic fracture zones. The Middle to Late Jurassic marine transgression across the continental margin correlates with the minimum late Oxfordian age of the adjacent deep sea floor, and the Late Cretaceous and Cenozoic carbonates of the margin provide a source for the Cenozoic displaced carbonates of the abyssal plains. These postulated connections are much less precise than those postulated for the southwest (Sites 263 and 259), as was to be expected for the reasons given above.

\section{Comparison of Marginal Oceanic and Continental Structure}

The western margin of the Australian continent and the ocean basins adjacent to it show a remarkable orthogonal arrangement of northwest- and northeasttrending lineaments, which coincide with the structural grain of the western part of the continent. This arrangement was noted earlier by Fairbridge (1955) and Teichert (1958): "Major geotectonic features of marginal Western Australia seem to extend not only across the continental shelf, but far out into the deep sea [Teichert, 1958, p. 581]."

The geology of the western part of Australia (Figure 15 ) is dominated by three large Archean shields. The largest, the Yilgarn Block, occupies the southwestern quarter of Western Australia and is ringed by belts of Proterozoic metamorphic rocks. To the north, the Pilbara Block is separated from the Yilgarn Block by a wide zone of tightly folded Proterozoic sedimentary and metamorphic rocks. The Kimberley Block is an almost square feature of Proterozoic rocks overlying fold/fault complexes incorporating Archean rocks along its southwestern and southeastern margins.

Between the Kimberley and Pilbara blocks lies the intracratonic Canning Basin, a gentle downwarp of thick $(6000 \mathrm{~m})$ Paleozoic sediments with a deep $(19,000$ $\mathrm{m})$ graben along its northern side adjacent to the Kimberley Block. On the southwest coast, west of the 


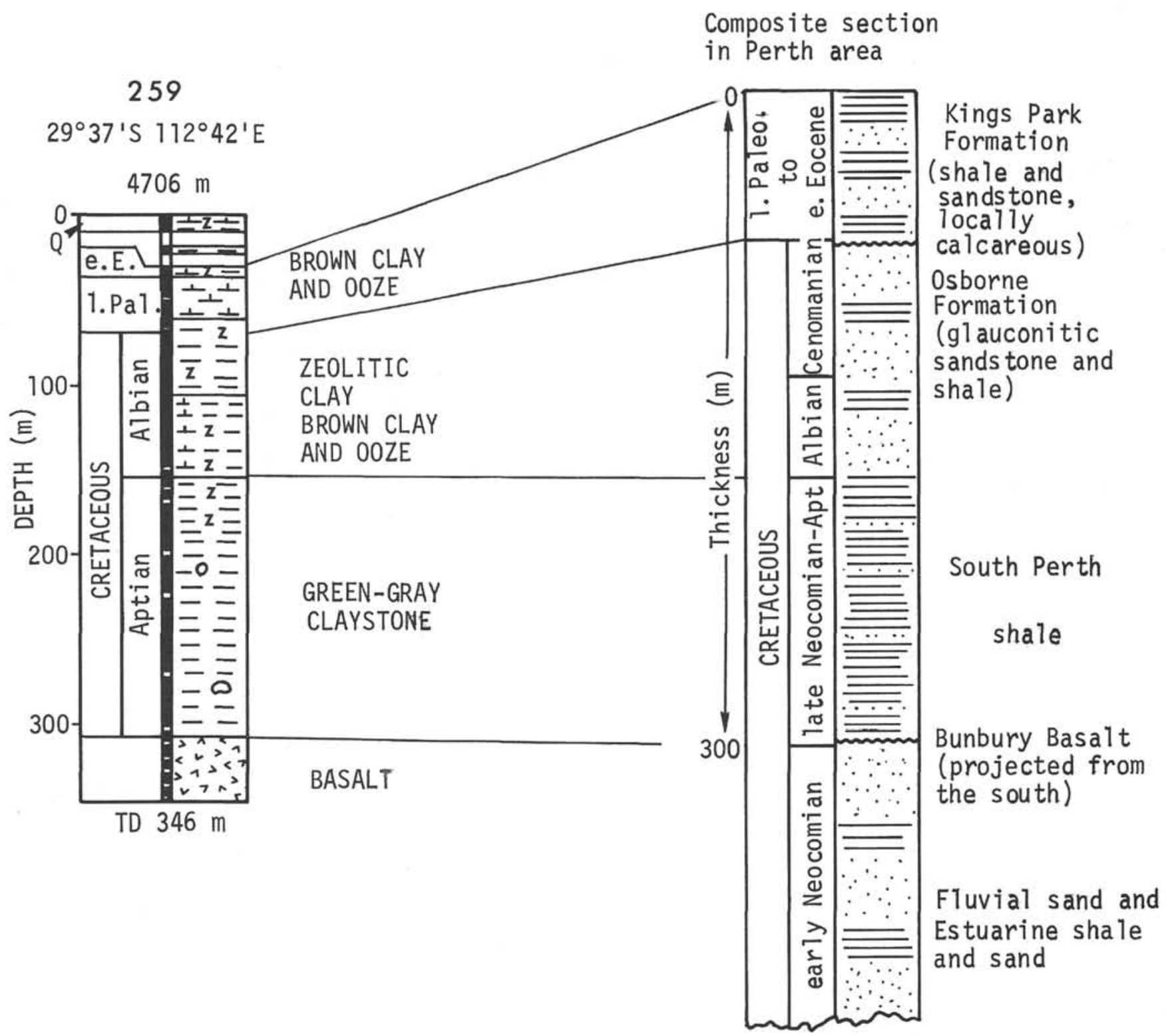

Figure 13. Comparison of stratigraphic section of Site 259 with composite stratigraphic section of Cretaceous and early Cenozoic rocks of the Perth area.

Pilbara and Yilgarn blocks, are the Carnarvon and Perth basins-fault-dominated sites of Paleozoic sedimentation which developed into deep rifts (structural relief up to $15,000 \mathrm{~m}$ ) in the Mesozoic, heralding the incipient breakup of the continental margin.

Northwest to north-northwest-trending lineaments are prominent over much of Western Australia. In the south they include the trend of greenstone and metasedimentary belts within the Archean Yilgarn Block, the prominent line of present-day seismicity (near Meckering), and a major fault direction in the onshore and offshore Perth Basin. To the north, this is the major trend of folds and faults in the Proterozoic south of the Pilbara Block, of the faults and basement-controlled structures in the Canning Basin, and of the major folds, faults, and joints of the Kimberley Block.

Offshore, lineaments of this trend form the WallabyPerth scarp, offshore fault and magnetic basement trends in the Perth Basin, both the northeast and southwest margins of the Cuvier Abyssal Plain, and the southwest margin of the offshore Bonaparte Gulf Basin.

Northeast-trending lineaments include the Hardabut Fault at the southern end of the Carnarvon Basin and Proterozoic flexures to the northwest of the Yilgarn Block. The most prominent of these lineaments is the major fault zone with some sinistral strike-slip component to the east of the Kimberley Block.

Offshore, the northeast trend can be recognized in the southeast margin of the Cuvier Abyssal Plain, parts of the northwest margins of the Exmouth and the Scott plateaus, the prominent northeast-trending faults of the Exmouth Plateau, the Rankin Trend and the fold trends of the Browse Basin and Sahul Banks, and the elongation of Timor.

The age of these structures ranges from Archean (2.7 b.y.) in the Yilgarn Block, through Proterozoic (2.0 to 

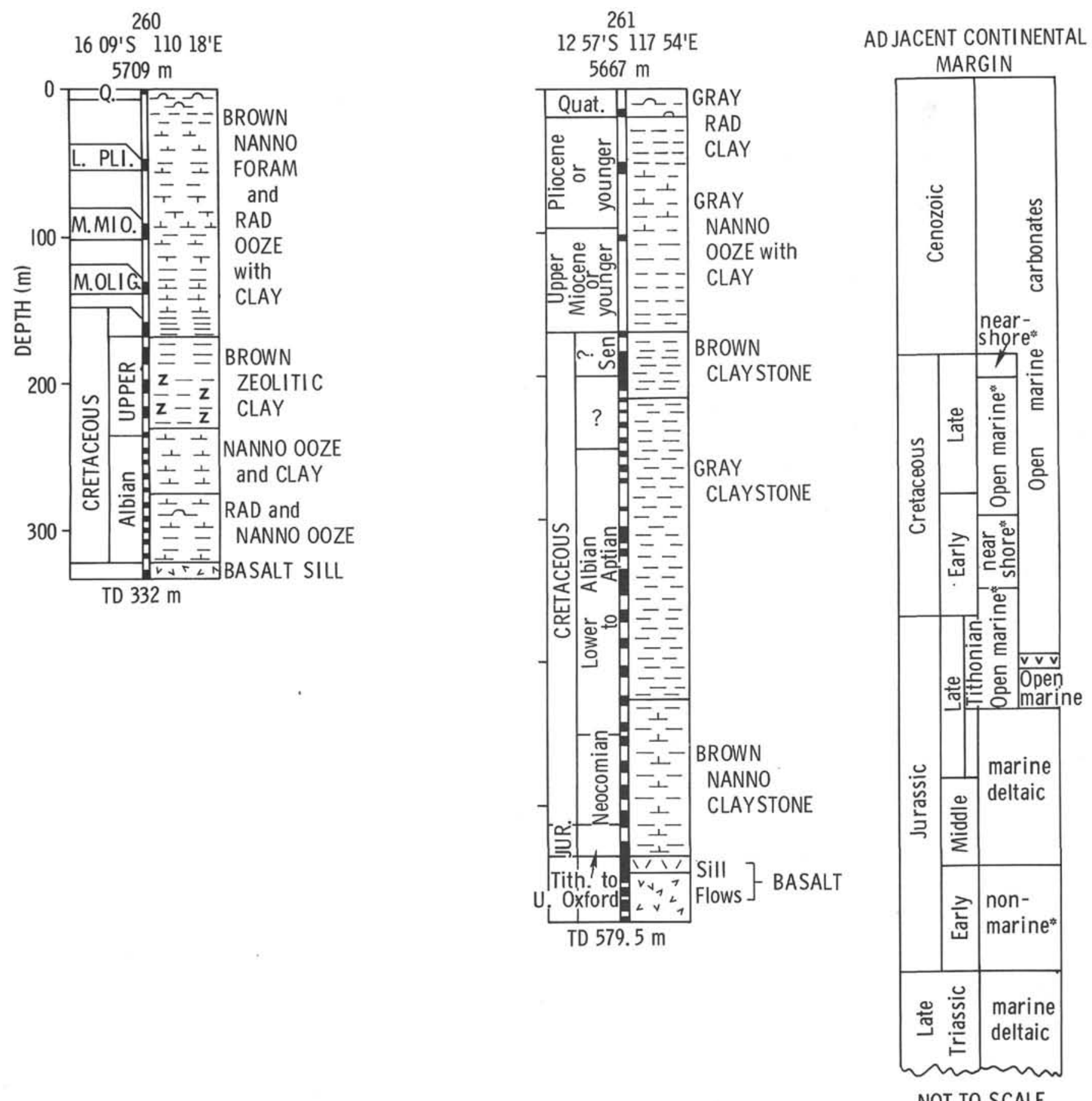

*Bedout-1

Figure 14. Comparison of stratigraphic sections of Sites 260 and 261 with qualitative column of the adjacent continental margin.

0.7 b.y.) in the Pilbara and Kimberley blocks, to Paleozoic and early to middle Mesozoic in the Perth, Carnarvon, Canning, and Bonaparte Gulf basins and on the offshore marginal plateaus, and late Mesozoic at the ocean-continent boundary.

The younger northwest trends of the Perth and Canning basins parallel the ancient ones of the adjacent Precambrian terrain, and we infer from this that these younger trends simply reflect the grain of the under- lying Precambrian rocks. Likewise, we infer that the Wallaby-Perth escarpment and the escarpments with similar trend which bound the Cuvier Abyssal Plain reflect original lines of weakness in the Precambrian crust along which major fractures have developed subsequently.

The northeasterly lineaments of the Exmouth Plateau (Veevers et al., in press), and the Rankin Trend (Kaye et al., 1972) are inferred to have formed during the Meso- 


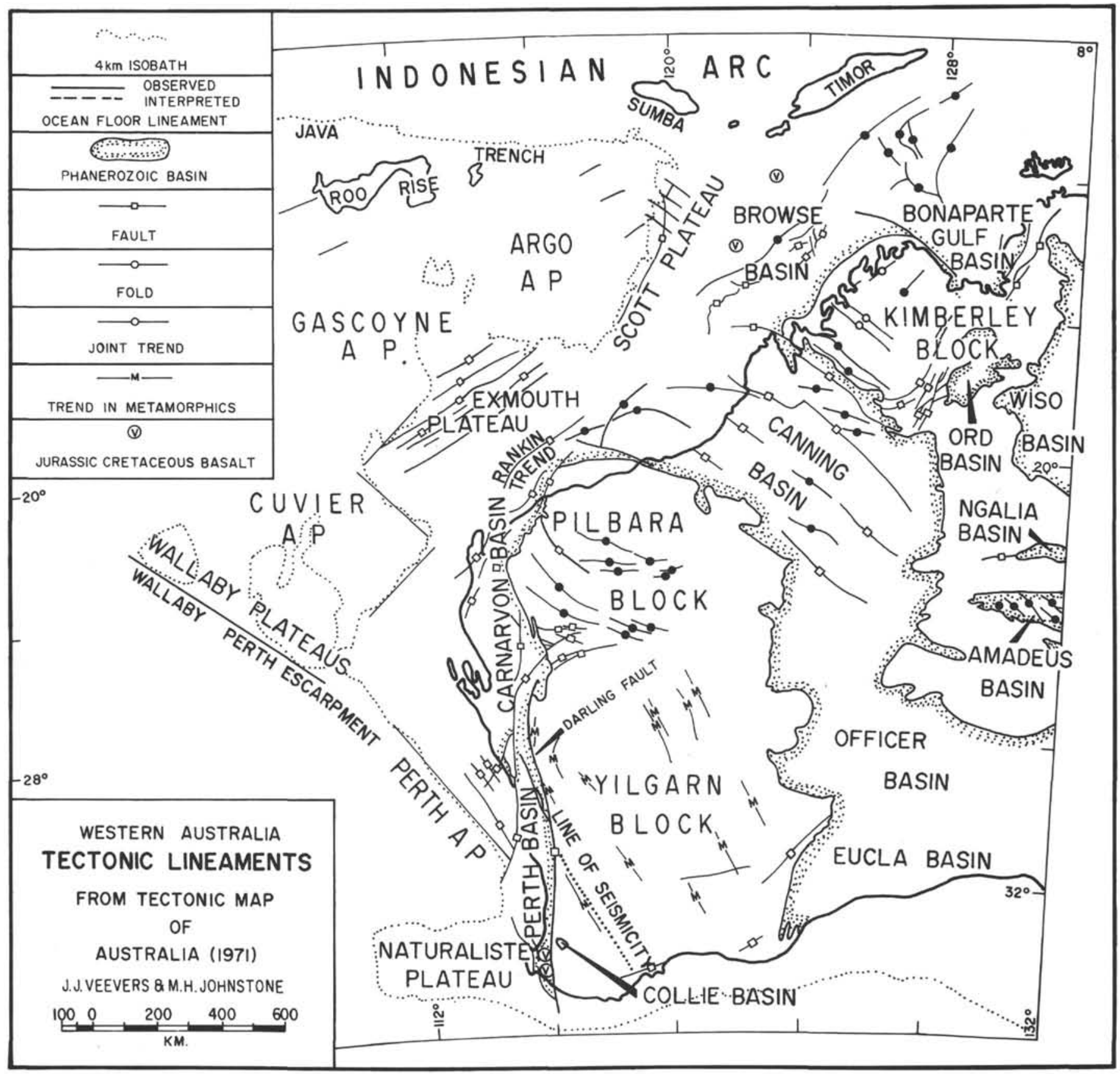

Figure 15. Tectonic lineaments of the floor of the eastern Indian Ocean and adjacent continent. The 4-km isobath marks the approximate boundary between oceanic and continental crust. Oceanic physiographic from Falvey and Veevers (in press) and, west of long $108^{\circ}$ E, from Kanaev (personal communication). Structure of Exmouth and Scott Plateaus from Veevers et al. (in press). Onshore structure from Tectonic Map of Australia (1971), with additional details from Jones and Pearson (1972) and Johnstone et al. (1973). Occurrences of Late Jurassic and Early Cretaceous basalt from Veevers (1969), Warris (1973), and Johnstone et al. (1973).

zoic phase of rifting which preceded continental dispersal. The only set of trends known from the sea floor off the northwest margin-the magnetic lineations between the Exmouth Plateau and Roo Rise, and in the northeast Argo Abyssal Plain (Falvey, 1972)-parallel the fault patterns on the continental margin.

The Darling Fault, which is a Proterozoic feature reactivated in the Permian and Mesozoic to form the eastern margin of the Perth and southern Carnarvon basins, trends in a north-south direction in marked contrast with the dominant northeast and northwest trends. This fault marks the western edge of the Archean Yilgarn Block and is flanked on the west by Proterozoic granulites and gneisses and its apparently anomalous trend is due to the rupturing of the crust along a Proterozoic line of weakness.

The relationship between continental lineaments and the direction of sea-floor spreading in the adjacent 
ocean is complex, as a glance at maps of the Red Sea and Gulf of California would show. We have noted above the parallelism of the fault trends of the Exmouth Plateau and the Rankin Trend with the magnetic lineations of the adjacent ocean floor, and hence with the direction of spreading. This topic is extended in the tectonic synthesis chapter, this volume.

\section{SUMMARY}

1. The connection between continental and oceanic stratigraphy and structure is strongest in the Carnarvon Basin-Cuvier Abyssal Plain area, where continuity of structure at the base of the Aptian, and initially shallowwater deposition towards the base of the Aptian beneath the Cuvier Abyssal Plain seem to imply a gradation of structure between the present deep ocean floor and the shallow continental margin.

2. At Site 259 the reflection of depositional events that took place on the adjacent continent likewise reveals a close connection between the ocean and continent, but continuity of structure is broken at the Wallaby-Perth scarp.

3. Comparison of the depositional sequence at Site 261 is hampered by its greater distance from drill holes on the adjacent continental margin.

4. The orthogonal lineaments of the Western Australian continental margin, including its boundaries with the ocean, reflect the structural grain of the ancient Precambrian basement. Locally these lineaments parallel oceanic lineaments (sea-floor-spreading magnetic anomalies) and hence the direction of spreading.

\section{ACKNOWLEDGMENTS}

We are indebted to Drs. D. A. Falvey, J. G. Jones, and C. M. Powell for discussing some of the ideas presented here, and to Dr. J. G. Jones for a critical review of the manuscript.

\section{REFERENCES}

Audley-Charles, M. G., 1968. The geology of Portuguese Timor: Mem. Geol. Soc. London, v. 4.

B. O. C. of Australia Ltd., in press. 1971 Bedout No. 1 completion report: Bur. Min. Res. Australia Petrol. Search Subsidy Acts Publ.

B. O. C. of Australia Ltd., in press. 1971 Scott Reef No. 1 completion report: Bur. Min. Res. Australia Petrol. Search Subsidy Acts Publ.

Burckle, L. H., Saito, T., and Ewing, M., 1967. A Cretaceous (Turonian) core from the Naturaliste Plateau, southeast Indian Ocean: Deep-Sea Res., v. 14, p. 421.

Condon, M. A., 1965-68. Geology of the Carnarvon Basin, W. A: Bur. Min. Res. Australia Bull. 77.

Crank, K., 1973. Geology of Barrow Island Oil Field: J. Australian Petrol. Explor. Assoc., v. 13, p. 49.

Fairbridge, R. W., 1955. Some bathymetric and geotectonic features of the eastern part of the Indian Ocean: Deep-Sea Res., v. 2, p. 161.

Falvey, D. A., 1972. Sea floor spreading in the Wharton Basin (Northeast Indian Ocean) and the breakup of Eastern Gondwanaland: J. Australian Petrol. Explor. Assoc., v. 12, p. 86.

Falvey, D. A. and Veevers, J. J., in press. Physiography of the Exmouth and Scott Plateaus and adjacent northeast Wharton Basin: Marine Geol.

Geary, J. K., 1970. Offshore exploration of the southern Carnarvon Basin. J. Australian Petrol. Explor. Assoc., v. 10, p. 9.
Geological Society of Australia, 1971. Tectonic map of Australia and New Guinea 1:5,000,000: Sydney.

Halse, J. W. and Hayes, J. D., 1971. The geological and structural framework of the offshore Kimberley Block (Browse Basin) area, Western Australia: J. Australian Petrol. Explor. Assoc., v. 11, p. 64.

Hayes, D. E., Frakes, L. A., Barrett, P. J., Burns, D. A., Chen, P. -H., Ford, A. B., Kaneps, A. G., Kemp, E. M., McCollum, D. W., Piper, D. J. W., Wall, R. E., and Webb, P. N., 1973. DSDP Leg 28: Geotimes, v. 18, p. 19.

Johnstone, M. H., Lowry, D. C., and Quilty, P. G., 1973. The geology of southwestern Australia-a review: J. Roy. Soc. W. Australia, v. 56, p. 5 .

Jones, D. K. and Pearson, G. R., 1972. The tectonic elements of the Perth Basin: J. Australian Petrol. Explor. Assoc., v. 12, p. 17.

Kaye, P., Edmond, G. M., and Challinor, A., 1972. The Rankin Trend, Northwest Shelf, Western Australia: J. Australian Petrol. Explor. Assoc., v. 12, p. 3.

Luyendyk, B. P., Davies, T. A., Rodolfo, K. S., Kempe, D. R. C., McKelvey, B. C., Leidy, R. D., Harvath, G. J., Hyndman, R. D., Theirstein, H. R., Boltovskoy, E., and Doyle, P., 1973. Across the southern Indian Ocean aboard Glomar Challenger: Geotimes, v. 18, p. 16.

McGowran, B., 1973. Rifting and drift of Australia and the migration of mammals: Science, v. 180, p. 759.

McWhae, J. R. H., Playford, P. E., Lindner, A. W., Glenister, B. F., and Balme, B. E., 1958. The stratigraphy of Western Australia: J. Geol. Soc. Australia, v. 4.

Mollan, R. G., Craig, R. W., and Lofting, M. J. W., 1970. Geologic framework of continental shelf off Northwest Australia: Am. Assoc. Petrol. Geol. Bull., v. 54, p. 583.

Moore, T. C., 1972. DSDP: successes, failures, proposals: Geotimes, v. 18, p. 27.

Sclater, J. G., von der Borch, C. C., Gartner, S., Hekinian, R., Johnson, D. A., McGowran, B., Pimm, A. C., Thompson, R. W., and Veevers, J. J., 1974. Initial Reports of the Deep Sea Drilling Project, Volume 22: Washington (U.S. Government Printing Office).

Teichert, C., 1958. Australia and Gondwanaland: Geol. Rundschau, v. 47 , p. 562.

Veevers, J. J., 1969. Palaeogeography of the Timor Sea region: Palaeogeog., Palaeoclimat., Palaeoecol., v. 6, p. 125.

1971. Phanerozoic history of Western Australia related to continental drift: J. Geol. Soc. Australia, v. 18, p. 87.

Veevers, J. J., Jones, J. G., and Talent, J. A., 1971. IndoAustralian stratigraphy and the configuration and dispersal of Gondwanaland: Nature, v. 229, p. 383.

Veevers, J. J., Falvey, D. A., Hawkins, L. V., and Ludwig, W. J., in press. Seismic reflection measurements of the northwest Australian margin: Am. Assoc. Petrol. Geol. Bull.

Veevers, J. J. and Evans, P. R., in press. Late Palaeozoic and Mesozoic history of Australia: Int. Gondwana Symp., 3rd, Canberra.

von der Borch, C. C., Sclater, J. G., Gartner, S., Hekinian, R., Johnson, D. A., McGowran, B., Pimm, A. C., Thompson, R. W., and Veevers, J. J., 1972. Deep Sea Drilling Project, Leg 22: Geotimes, v. 17, p. 15-17.

Warris, B. J., 1973. Plate tectonics and the evolution of the Timor Sea, northwest Australia: J. Australian Petrol. Explor. Assoc., v. 13, p. 13.

Wellman, P., McElhinny, M. W., and McDougall, I., 1969. On the polar-wander path for Australia during the Cenozoic: Geophys. J. Roy. Astron. Soc., v. 18, p. 371.

Williams, C. T., in press. 1971 Wapet Gage Roads-2 completion report. Bur. Min. Res. Australia Petrol. Search Subsidy Acts Publ. 